\title{
Myroridin, a New Peptide Antibiotic from Myrothecium SP. 285F
}

\author{
SHigedi Kondo \\ Sendai Municipal Institute of Public Health, Sendai 980
}

Kondo, S. Myroridin, a New Peptide Antibiotic from Myrothecium SP. $285 \mathrm{~F}$ Tohoku J. exp. Med., 1977, 122 (4), 403-404 — Myroridin, a new basic peptide antibiotic was isolated from culture filtrate of a strain of Myrothecium, No. $285 \mathrm{~F}$. The present paper describes the production, isolation and characterization of this antibiotic. Myrothecium; myroridin; peptide antibiotic

Myroridin was produced by fermenting a strain of Myrothecium, No. $285 \mathrm{~F}$, at $24 \sim 28^{\circ} \mathrm{C}$ for $14 \sim 16$ days in a jar fermentor. The taxonomic characteristics of the strain No. $285 \mathrm{~F}$ are very similar to those of $M$ yrothecium roridum. The fermentation medium contained $3.0 \%$ glucose, $1.0 \%$ polypeptone, $0.2 \% \mathrm{NaNO}_{3}, 0.1 \% \mathrm{KH}_{2} \mathrm{PO}_{4}, 0.05 \% \mathrm{KCl}, 0.05 \% \mathrm{MgSO}_{4}$. $7 \mathrm{H}_{2} 0,0.001 \% \mathrm{FeSO}_{4} \cdot 7 \mathrm{H}_{2} \mathrm{O}$. To remove cationic impurities, the culture filtrate was applied to the IRC-50 (H-type) column. The antibiotic was eluted with $1 \mathrm{~N} \mathrm{HCl}$. After concentration of the eluate, the aqueous solution of the antibiotic was precipitated with acetone-ethanol $(4: 1)$ and then the precipitate was dissolved in methanol. Methanol was evaporated and thus crude powder was obtained. When the crude powder was dissolved in methanol, washed with acetone, dissolved in water, and applied to a column of $\mathrm{Al}_{2} \mathrm{O}_{3}$, or Biogel P-2 or CM Sepadex, two major peaks which were named Fraction I and Fraction II were obtained.

The optical rotation of Fraction I was $[a]_{D}^{22}+0.2\left(\mathrm{c}=1 \%, \mathrm{H}_{2} \mathrm{O}\right)$. The elementary analysis gave the following composition: $\mathrm{C} 40.19 ; \mathrm{H} 6.90 ; \mathrm{N} 17.27 ; \mathrm{Cl} 14.58(\%)$. The molecular weights estimated by means of gel filtration, freezing point and steam distillation were 1300,1300 and 1200 , respectively. It melts at $192 \sim 198^{\circ} \mathrm{C}$ with decomposition. The ultraviolet absorption spectrum in methanol exhibited the maximum absorption at $278 \mathrm{~nm}\left(\mathrm{E}_{\mathrm{lcm}}^{1 \%}=1175\right)$. Fig. 1 shows the IR spectrum in $\mathrm{KBr}$. Hydrolysis in $6 \mathrm{~N} \mathrm{HCl}$ at $110^{\circ} \mathrm{C}$ for $24 \mathrm{hr}$ in a sealed tube and subsequent amino acid analysis revealed the predominant presence of arginine, threonine, hydroxyarginine, tyrosine, ornithine and lysine in Fraction $\mathbf{I}$.

The optical rotation of Fraction II was $[a]_{D}^{22}+0.6\left(c=1 \%, \mathrm{H}_{2} \mathrm{O}\right)$. The elementary
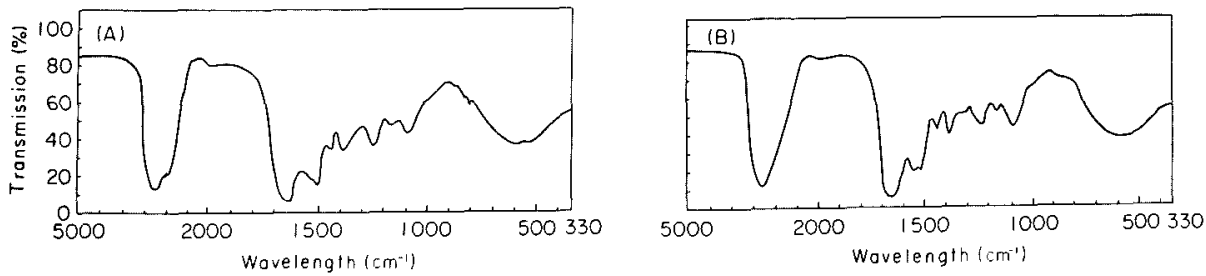

Fig. 1. Infrared spectra of Fraction I (A) and Fraction II (B).

Received for publication, April 21, 1977. 
analysis gave the following composition: $\mathrm{C} ; 37.78 ; \mathrm{H} 6.77 ; \mathrm{N} 19.53 ; \mathrm{Cl} 13.29 \%$. The molecular weights determined by gel filtration, freezing point and steam distillation were 1200, 1220 and 1200 , respectively. It melts at $197 \sim 203^{\circ} \mathrm{C}$ with decomposition. The ultraviolet absorption spectrum in methanol exhibited the maximum absorption at 278 $\mathrm{nm}\left(\mathrm{E}_{1 \mathrm{~cm}}^{1 \%}=1175\right)$. The infrared spectrum in $\mathrm{KBr}$ tablet is shown in Fig. $\mathrm{I}(\mathrm{B})$. Hydrolysis in $6 \mathrm{~N} \mathrm{HCl}$ at $110^{\circ} \mathrm{C}$ for $24 \mathrm{hr}$ in a sealed tube and subsequent amino acid analysis revealed the predominant presence of arginine, threonine, hydroxyarginine, tyrosine and ornithine in Fraction II. The behaviors of Fraction 1 or 2 towards chemical test in color reaction were exactly the same. Namely, they gave positive reactions to Ninhydrin, Xanthoprotein, Millon, Sakaguchi and Pauli, but negative to Molish, Tollens and Sodium nitroprusside. Also in precipitation reaction they gave positive formations to phosphotungustic acid, picric acid, flavianic acid, pentachlorophenol and benzaldehyde. They are soluble in water and methanol, and insoluble in ethanol, acetone, ether, benzene, chloroform, n-hexane, cyclohexane and petroleum ether. The nitrogen content, the behavior in color reaction and the absorption bands of amide linkages in the infrared absorption spectrum indicate the peptide nature of Fraction I and Fraction II.

TABLE 1. Antimicrobial spectrum of Fraction $I$ and Fraction $I I$

Fr. I 0.2, Fr. II 0.4: Candida albicans, Candida tropicalis, Candida pseudotropicalis, Candida utilis, Candida guillermondai, Candida krusei, Saccharomyces cerevisiae $\mathrm{Br}-60$, Saccharomyces rouxii Boutroux, Zygosaccharomyces salsus, Willia anomala, Hansenula anomala, Torulaspora delbruecki, Rhodotorula rubra, Mycotorula japonica, Debaryomyces klockeri, Pullularia pululans

Fr. I 20, Fr. II 40: Proteus OX-19

Fr. I $>100$, Fr. II $>100:$ Bacillus subtilis, Staphylococcus aureus 209-P, Escherichia coli, Shigella sonnei, Sarcina lutea Hata, Bacillus mycoides

Fr. I $>1000$, Fr. II >1000: Mycabacterium timothee, Mycobacterinm smegmatis, Mycobacterium $\mathrm{H}_{37} \mathrm{RV}$, Trichophyton asteroides, Trichophyton rubrum, Trichomonas vaginalis

As shown in Table 1, the antibiotic was effective against yeasts, but inactive against other Gram-positive bacteria, Gram-negative bacteria and Mycobacterium.

Acute toxicities of Fraction $I$ in mice were $144 \sim 172.8 \mathrm{mg} / \mathrm{Kg}, 360 \sim 432 \mathrm{mg} / \mathrm{Kg}, 320 \sim$ $500 \mathrm{mg} / \mathrm{Kg}$ and $>6000 \mathrm{mg} / \mathrm{Kg}$ upon intravenous, intraperitoneal, subcutaneous and oral administration, respectively. Its subacute toxicity in Douryu rat was $200 \sim 400 \mathrm{mg} / \mathrm{Kg}$ intraperitoneally. Fraction II exhibited almost the same toxicity as Fraction I.

The further characterization and the clarification of the mechanism of action of myroridin are in progress.

\section{Acknowledgments}

I deeply appreciate the kind advices and suggestions of Prof. N. Ishida, Prof. S. Kimura, Prof. K. Kumagai, and Dr. F. Suzuki, Tohoku University, and Dr. T. Fujii, and Dr. I. Hayashi, Research Department, Kakenyaku Kako Co. 